\title{
Chayote (Sechium edule): a review of nutritional composition, bioactivities and potential applications
}

Corresponding author: E-mail address: elsavieiraf@gmail.com (Elsa F. Vieira). Tel: +351-228340500| ext. 1286.

\section{ABSTRACT}

Chayote (Sechium edule) has gained widespread consuming acceptance and recognized by its nutritional and bio-functional properties. The present review surveys and describes the current findings about the nutritional, phytochemical and pharmacological properties of chayote and identifies opportunities for further research. It also discusses chayote's versatile utility in nutrition, as a functional ingredient in food, cosmetic and

pharmaceutical industries, as well as in nanotechnology and biotechnological processes. It was concluded that although the pharmacological properties of chayote are currently well-established, only a few reports have been conducted on the isolation and identification of individual chemical constituents, and similarly, only a few in vivo studies have been conducted to assess their biological efficacy. In addition, the valorisation of the underutilized chayote by-products can be an important aspect in waste management from both economic and environmental standpoints. Thus, the recovery and utilization of valuable compounds from chayote is an important challenge for scientists.

Keywords: chayote, bioactive compounds, health-benefits, valorisation. 


\section{Introduction}

Sechium edule (Jacq.) Swartz is a herbaceous perennial climbing plant with tendrils and tuberous roots, cultivated since pre-Colombian times in Mexico (Cadena-Iñiguez et al., 2007). The edible fruit is popularly known as chayote, christophene, vegetable pear, mirliton, merleton choko (in Australia and New Zealand), starprecianté, citrayota, citrayote (Ecuador and Colombia), chuchu (Brazil), machucha, caiota, pipinela

(Portugal), chow chow (India), cho cho (Jamaica), Sayote (Philippines), güisquil (Guatemala, El Salvador), pear squash or iskus (Nepal) (Bermejo \& León, 1994; Lim, 2012). The main producer countries of chayote include Mexico, Costa Rica, Brazil and the Dominican Republic (Lim, 2012). According to the most recent report, Costa Rica exports predominantly to the European Union, whereas Mexico exports to the United States and Canada (Cadena-Iñiguez et al., 2007). In these countries chayote has been set in fourth place of the most consumed imported products, after avocado, tomato and coffee (Cadena-Iñiguez et al., 2007). In addition to the fruits, stems and tender leaves (usually known as "quelites"), the tuberous parts of the roots (in Mexico called "chayotextle", “cueza", “camochayote", and "chinchayote") are also eaten (Hernandez-Uribe, Agama-Acevedo, Gonzalez-Soto, Bello-Pérez, \& Vargas-Torres, 2011). The consumption of the fruit is much appreciated using conventional cooking methods, such as simply boiled or used in stews and desserts (Saade, 1996), whereas the peel and leaves are usually poorly consumed, presenting however promising health properties, such as a diuretic or kidney stones dissolving capacity (Loizzo, Bonesi, Menichini, Tenuta, Leporini, \& Tundis, 2016). Chayote's versatile utility in nutrition, folk medicine and as a functional food ingredient has been reported by several researchers. However, so far, there is no available updated review that focuses on all aspects of this valuable vegetable. This prompted us to compile the data published on the nutritional, 
phytochemistry and pharmacological properties of chayote in the form of a comprehensive review.

\section{Taxonomy, botanical description and production}

Chayote is taxonomically classified within Embryophytes; class Magnoliopsida; order Violales; family Cucurbitaceae (along with bitter apple, gourd, cucumber, melon, and pumpkin); genre Sechium and species Sechium edule Jacq Sw. (Saade, 1996; Lim, 2012). There are few reports available regarding the genetic diversity of chayote (Cadena-Iñiguez et al., 2007; Machida-Hirano, Cortés-Cruz, González, Íñiguez, Shirata, \& Watanabe, 2015). Sechium edule species presents a wide variation regarding the form and colour of fruits, many of which are only known on local markets. There are ten species currently accepted to exist, eight of which are wild (S. Chinantlense, S. compositum, $S$. hintonii, S. talamancense, S. panamense, S. pittieri, S. venosum and S. vilosum) and two cultivated (S. tabaco and S. edule) (Saade, 1996). Despite the large variety of Sechium edule commercially cultivated, only the Viren levis, called "smooth green", has been utilized for large-scale exploitation. Mexico has been the main producer and exporter of “smooth green” chayote worldwide (Cadena-Iñiguez et al., 2007).

Botanically, chayote plant grows from a single thick root, which produces adventitious tuberous roots (Fig. 1). The stems are several metres long, slightly compressed and longitudinally furrowed. The flowers are unisexual and the leaves are slightly lobate (with three to five angular lobes) and have minutely denticulate margins and three to five divided tendrils. The fruits are pear shaped and grow either individually or in pairs on a shared peduncle. They are fleshy or fleshy-fibrous, may have longitudinal ridges or furrows, and come in many different shapes (globose, ovoid, subovoid, pyriform), sizes (4.3-26.5 $\mathrm{cm}$ long, 3-11 cm wide), number and type of spines, and colours 
(white and yellowish or pale green to dark green). The fruit is highly perishable and, unlike other cucurbits, contains only a single seed, which is compressed, smooth and can germinate and send out a shoot within thirty days of harvesting. In cultivated plants, the seed germinates when the fruit is still on the plant, while in wild plants only once the fruit becomes detached (Aung, Ball, \& Kushad, 1990; Bermejo \&

León, 1994; Saade, 1996; Cadena-Iñiguez et al., 2007).

Chayote can grow with relative ease due to its adaptability to a wide range of climatic conditions. It is a traditional practice of homeowners to plant chayote to run along fences, over shrubs and even straight up trees. The most suitable average temperature is $13-21{ }^{\circ} \mathrm{C}$; temperatures of less than $13{ }^{\circ} \mathrm{C}$ damage fruit while those above $28{ }^{\circ} \mathrm{C}$ favour excessive growth and the falling of flowers and immature fruits (Saade, 1996). Chayote is a self-sufficient plant resistant to most diseases and pests, mostly caused by fungi (Ascochyta phaseolorum and various species of Fusarium, Macrophomina and Colletotrichum), and sometimes by nematodes (Meloidogyne incognita and Helicotylenchus sp.) and insects (Empoasca Solana) (Aung et al., 1990; Saade, 1996). Several chemical products are available for controlling pests and diseases. Alternately, they can be controlled manually by removing the damaged part of the plants or adopting the rotation of plantations crops. The storage life of chayote is 4-6 weeks in optimal storage conditions, recommended at $7{ }^{\circ} \mathrm{C}$ and $85-90 \%$ humidity level (Sargent \& Maynard, 2009). Under higher storage temperatures, 25,15 or $10^{\circ} \mathrm{C}$, chayote can lose, respectively, $1.3 \%, 0.5 \%$ and $0.02 \%$ of the fresh weight per day. The most efficient practice to promote the shelf-life of chayote (and protecting fruit packed for exportation) is the use of a polyvinyl chloride film overwrap, which retards weight loss by $80 \%$ to $90 \%$. Although this practice reduces loss of humidity, may also increase the incidence of 
pathogen Mycovellosiella cucurbiticola. This problem, as well as the chilling injury, can be controlled through the use of antitranspirants (Sargent \& Maynard, 2009).

\section{Nutritional properties}

\subsection{General}

The nutritional composition of chayote is influenced by the climate, region, growing conditions, age of the plant and the processing methods. Although the mature green fruit is the most commonly consumed portion of the plant, the immature fruits, young leaves, shoots, and the tuberous roots can also be eaten, providing an important source of nutrients (Bermejo \& León, 1994). A summary of the nutritional composition of the different edible parts of chayote is presented in Table 1. Chayote fruit can be consumed raw in salad, casseroled, creamed, curried, fried, scalloped, sautéed or pickled (Aung et al., 1990; Saade, 1996).

\subsection{Chayote fruit and peels}

Due to its high moisture content (89-95 g/100 g), Table 1, chayote falls in the category of a "fleshy vegetable". The chayote fruit is harvested and consumed still immature, because it becomes harder and fibrous during the maturation process, due to the decrease of branched arabinan and arabinogalactan contents (Shiga, Peroni-Okita, Carpita, Lajolo, \& Cordenunsi, 2015). In a raw state, the pulp has a firm and crispy texture that becomes delicate after cooking; its flavour vary according to cultivar, from bland to sweetish or starchy (Shiga et al., 2015; Mishra \& Das, 2015). The fruit is relatively low in calories, 19-31 Kcal/100 g dry weight (dw), being lower than the calories provided by young stems $(60 \mathrm{Kcal} / 100 \mathrm{~g} \mathrm{dw})$ and tuber roots $(80 \mathrm{Kcal} / 100 \mathrm{~g} \mathrm{dw})$. The protein $(0.82-1.74 \mathrm{~g} / 100 \mathrm{~g}$ $\mathrm{dw})$, starch (0.20-1.56 g/100 g dw) and lipid contents (0.10-0.30 g/100 g dw) are relatively 
low and the lipid fraction is mostly represented by palmitic acid (39.6\%), linolenic (18\%), stearic $(16.8 \%)$, oleic $(11.2 \%)$, linoleic $(8.87 \%)$, and palmitoleic acids $(3.15 \%)$ (Del Ángel Coronel, 2015). The fibre content of fruit $(0.40-7.60 \mathrm{~g} / 100 \mathrm{~g} \mathrm{dw})$ is higher as compared to roots $(0.17-0.40 \mathrm{~g} / 100 \mathrm{~g} \mathrm{dw})$, but lower than stems $(1.20-21.7 \mathrm{~g} / 100 \mathrm{~g} \mathrm{dw})$ and leaves (1.10-12.1 g/100 g dw).

The polysaccharide fraction, including glucurono(arabino)xylan, mannan, galactoglucomannan and fucoxyloglucan, is primarily present in the cell wall, thus contributing to the fruit's tissue structure (Shiga et al., 2015; Castro-Alves \& do Nascimento, 2016). The linear arabinan- and galactan-rich pectic material presents higher water holding capability, being suitable as a thickener in the food industry (Shiga et al., 2015). Chayote fruit contain $0.40-3.60 \% \mathrm{dw}$ of ash, which contains several minerals, including potassium $(125-338 \mathrm{mg} / 100 \mathrm{~g})$, calcium $(12-25 \mathrm{mg} / 100 \mathrm{~g})$, phosphorus (4-60 $\mathrm{mg} / 100 \mathrm{~g})$ and magnesium $(12-15.4 \mathrm{mg} / 100 \mathrm{~g})$. Moreover, it is also a rich source of certain essential amino acids, including valine $(0.99 \mathrm{mg} / \mathrm{g}$ protein $)$, leucine $(1.21 \mathrm{mg} / \mathrm{g}$ protein $)$, isoleucine $(0.70 \mathrm{mg} / \mathrm{g}$ protein $)$, phenylalanine $(0.75 \mathrm{mg} / \mathrm{g}$ protein $)$, threonine ( $0.64 \mathrm{mg} / \mathrm{g}$ protein $),$ lysine $(0.42 \mathrm{mg} / \mathrm{g}$ protein $)$, arginine $(0.54 \mathrm{mg} / \mathrm{g}$ protein $)$ and histidine $(0.23 \mathrm{mg} / \mathrm{g}$ protein $)$. Depending on the chayote variety, the immature raw fruits are rich in vitamins $\mathrm{C}(7.7-20 \mathrm{mg} / 100 \mathrm{~g} \mathrm{dw}), \mathrm{E}(0.12 \mathrm{mg} / 100 \mathrm{~g} \mathrm{dw})$ and folic acid $(93.0 \mu \mathrm{g} / 100 \mathrm{~g}$ $\mathrm{dw})$. The peels fraction contain $8.31 \% \mathrm{dw}$ of ash, which is mostly represented by calcium (307 mg/100 g), phosphorus (196 mg/100 g) and iron

(6.72 mg/100 g), Table 1.

\subsection{Chayote seeds}

As shown in Table 1, chayote seeds contains approximately $5.50 \mathrm{~g} / 100 \mathrm{~g} \mathrm{dw}$ of protein content, mainly composed by the essential amino acids leucine (2.69 mg/g protein), 
arginine (2.50), phenylalanine (1.81), valine (1.74), lysine (1.53), isoleucine (1.30), threonine (0.88) and histidine (0.67), indicating a good protein quality (Flick, Aung, Ory, \& Angelo, 1977; Siciliano et al., 2004). Seed is also a good source of carbohydrates (60.0 $\mathrm{g} / 100 \mathrm{~g} \mathrm{dw})$, namely starch $(1.90 \mathrm{~g} / 100 \mathrm{~g} \mathrm{dw})$. The lipid content is

around

$0.40 \mathrm{~g} / 100 \mathrm{~g} \mathrm{dw}$, whereas the maximum content is reached 5 days postharvest

$(29.1 \mathrm{~g} / 100 \mathrm{~g} \mathrm{dw})$ and the minimum value $(0.96 \mathrm{~g} / 100 \mathrm{~g} \mathrm{dw})$ after 29 days postharvest. Immature seeds of chayote are a rich source of the growth substances Gibberellins, mostly 3- and-or 13-hydroxylated, which are responsible for the rapid growth of the seed and fruit (Albone, Gaskin, MacMillan, \& Sponsel, 1984; Aung et al., 1990).

\subsection{Chayote tubers}

The starch content $(73 \mathrm{~g} / 100 \mathrm{~g} \mathrm{dw})$ of chayote tubers is very similar to that reported for the potato tuber $(70 \mathrm{~g} / 100 \mathrm{~g} \mathrm{dw})$ and contains low amounts of slowly digestible and resistant starch, but high levels of rapidly digestible starch (Jiménez-Hernández, SalazarMontoya, \& Ramos-Ramírez, 2007; Hernandez-Uribe, García-Suárez, Gutiérrez-Meraz, Rodriguez-Ambriz, \& Bello-Perez, 2014). When compared to potato starch, chayote tuber starch presents a higher degree of purity (> 98\%) (JiménezHernández et al., 2007), better thermal and pasting properties, and higher peak viscosity (mostly attributed to the higher content of phosphorus and amylopectin), but lower gelatinization temperatures (Hernandez-Uribe, Agama-Acevedo, Gonzalez-Soto, BelloPérez, \& Vargas-Torres, 2011). Hence, starch from chayote tuber could be used as a thickening agent in food dispersions where a high viscosity is needed (Jiménez-

Hernández et al., 2007). 


\subsection{Chayote roots}

Chayote plant produce the tuberized root after the first year of growth and can produce up to $5-\mathrm{kg}$ of tubers containing more than $65 \%$ starch $(\mathrm{w} / \mathrm{w} \mathrm{dw})$ after 2 years of growth (Saade, 1996). The roots, which possess a white colour and taste like potatoes after cooking, are highly appreciated throughout all Latin American countries (Shiga et al.,

2015). Compared to chayote fruits, there is scarce information about the root's nutritional composition and uses. One hundred grams of dried root contain on average 17.8-85.5 g carbohydrates, 13.6-72.8 g starch, 0.17-0.40 g fibre, 2.00-10.4 g protein and 0.20-0.33 g lipids (Table 1). Starch $(\sim 67 \%)$ and total soluble sugars contents $(\sim 2 \%)$ corresponded approximately to $50 \mathrm{kcal} / 100 \mathrm{~g}$ of available energy (Shiga et al., 2015). Chayote roots present a cell-wall structure comparable to that found in potato, sweet potato, and cassava. They are mostly composed by high amounts of cellulose (92\% in raw samples and $88 \%$ in cooked samples) and hemicellulose, medium amounts of pectin and high amount of glucose (47\%) (Shiga et al., 2015). For this reason, chayote tubers could be used for starch isolation, being an excellent alternative to potato and maize starches.

\subsection{Chayote leaves and stems}

Leaves possess significant amounts of protein $(2.69-4.88 \mathrm{~g} / 100 \mathrm{~g} \mathrm{dw})$, pectin $(0.45 \mathrm{~g} / 100$ $\mathrm{g} \mathrm{dw})$ and lipids (0.40-2.32 g/100 g dw), of which $40.2 \%$ are non-polar lipids, $30.8 \%$ glycolipids, and 29.0\% phospholipids (Rao, Dominic, Singh, Kaluwin, Rivett, \& Jones, 1990). The predominant fatty acids include the linolenic (42.1-76.7\%), palmitic (13.7-38.5\%) and linoleic (5.7-15.3\%) acids (Rao et al., 1990). Except for aspartic acid, the amino acid content of chayote leaves is relatively higher than fruits or seeds. Stems possess a fibre content of $1.20-21.70 \%$, a protein content of $4 \%$ and are particularly rich 
in niacin $(1.10 \mathrm{mg} / 100 \mathrm{~g} \mathrm{dw})$, vitamin A (615 UI/100 g dw) and vitamin E (90 mg/100 g dw), (Table 1).

\section{Bioactive compounds and functional food potential}

\subsection{General}

Chayote edible parts contain a wide diversity of bioactive compounds, such as peroxidases, alkaloids, saponins, phenolic acids, flavonoids, carotenoids, cucurbitane triterpenoids and phytosterols (Siciliano et al., 2004; Cadena-Iñiguez et al., 2007). While the potential health benefits of these bioactive compounds have received ample attention through the numerous in vitro studies, only few reports have been conducted on the isolation, identification of individual chemical constituents, as well as on the biological efficacy through in vivo studies. A comprehensive literature review of biological activities and chemical constituents found in chayote is shown in Table 2. The data are not comparable because various extractions and quantification procedures were used in the different experiments.

\subsection{Polyphenol compounds}

A broad-spectrum of polyphenols (phenolic acids, tannins and stilbenes) have been identified in chayote. Their presence is implicated in several purposes, such as protecting against fungal diseases and insect attack, imparting taste and providing aroma and colour. Furthermore, specific polyphenol compounds are known to have antiallergic, antiinflammatory, antiviral, anticarcinogenic and hypoglycemic effects (Loizzo et al., 2016). Siciliano et al. (2004) observed higher contents of flavonoids, including coumarins, anthroquinones, anthocyanins and phenolic acids, in the leaves $(0.35 \mathrm{~g} / 100 \mathrm{~g} \mathrm{dw})$, followed by roots $(0.31 \mathrm{~g} / 100 \mathrm{~g} \mathrm{dw})$ and stems $(0.19 \mathrm{~g} / 100 \mathrm{dw})$. According to this study, chayote stems presented higher content of apigenin $6-C-\beta-D$ glucopyranosyl- $8-C-\beta-D-$ 
apiofuranoside $(0.133 \mathrm{~g} / 100 \mathrm{~g} \mathrm{dw})$ and diosmetin 7-Orutinoside $(0.012 \mathrm{~g} / 100 \mathrm{~g} \mathrm{dw})$ than leaves and roots. Roots contain the highest content of vicenin-2 $(0.147 \mathrm{~g} / 100 \mathrm{~g} \mathrm{dw})$ and vitexin $(0.151 \mathrm{~g} / 100 \mathrm{~g} \mathrm{dw})$, and leaves contain the highest amount of luteolin 7-Orutinoside $(0.141 \mathrm{~g} / 100 \mathrm{~g} \mathrm{dw})$, luteolin $7 O-\beta-D-$

glucoside $(0.135 \mathrm{~g} / 100 \mathrm{~g} \mathrm{dw})$ and apigenin 7-O-rutinoside $(0.018 \mathrm{~g} / 100 \mathrm{~g} \mathrm{dw})$. More recently, Ragasa, Biona and Shen (2014) found that trans-cinnamic acid, phenylacetic acid, 3-octadecenoic acid, trilinolenin and $\alpha$-linolenic acid were presented in chayote leaves. Also, Chao et al. (2014) reported that the phenolic content of leaf extract of green chayote, $0.262 \mathrm{~g} \mathrm{GAE} / 100 \mathrm{~g}\left(\mathrm{IC}_{50}\right.$ of $\left.1801 \mu \mathrm{g} / \mathrm{ml}\right)$ was higher than the yellow chayote, $0.063 \mathrm{~g} \mathrm{GAE} / 100 \mathrm{~g}\left(\mathrm{IC}_{50}\right.$ of $\left.1503 \mu \mathrm{g} / \mathrm{ml}\right)$.

\subsection{Vitamins and carotenoids}

Several epidemiological studies have stated an inverse relationship between cancer and the dietary intake of vitamin $\mathrm{C}$ and $\beta$-carotene (Rietjens et al., 2002). As shown in Table 2, chayote fruit, peel and leaves are rich in vitamin $\mathrm{C}$ and carotenoids (lutein and $\beta$ carotene). The highest vitamin $C$ contents are presented in peel $(51.6 \mathrm{mg} / 100 \mathrm{~g} \mathrm{dw})$, followed by fruit $(5.5 \mathrm{mg} / 100 \mathrm{~g} \mathrm{dw})$ and leaves $(4.6 \mathrm{mg} / 100 \mathrm{~g} \mathrm{dw})$. According to Bellur and Prakash (2015), the total carotenoids of chayote peel is $1.7 \mathrm{mg} / 100 \mathrm{~g}$ dw and the $\beta$ carotene content is $0.36 \mathrm{mg} / 100 \mathrm{~g} \mathrm{dw}$. Leaves presents lutein $(7.4 \mathrm{mg} / 100 \mathrm{~g} \mathrm{fw})$ and Bcarotene (4.4 mg/100 g fw) (Sriwichai, Berger, Picq, \& Avallone, 2016).

\subsection{Polysaccharides}

Chayote fruits, leaves and tuberous roots contain bioactive polysaccharides. The beneficial activities of cell-wall polysaccharides are highly dependent on structure that 
confers important characteristics, such as water holding properties, solubility and availability for fermentation by colonic bacteria (Shiga et al., 2015).

\subsection{Sterols, triterpenes and cucubitacins}

The sterol composition of aerial sections of a mature plant $(16 \mathrm{mg} / 100 \mathrm{~g} \mathrm{dw})$ and pericarp (38 mg/100 g dw) of chayote purchased locally in Japan was reported by Akihisa, Ghosh, Thakur, Rosenstein and Matsumoto (1986). Gas liquid chromatography allowed the identification of twenty-three sterols, mostly represented by 24ethylcholesta-7,22-dienol (59.6\% and $23.0 \%$ in aerial sections and pericarp, respectively), 24-ethylcholest-7-enol + 24-ethylcholesta-7,25-dienol (22.8\% and 46.2\%, respectively), 24-ethylcholesta-7,22,25trienol (6.7\% and 15.2\%, respectively) and 24methylcholest-7-enol (2.9\% and 4.3\%, reespectively). These authors also identified fourteen triterpene alcohols, including $\alpha-$ Amyrin (urs-12-enol) (31.5\% and $11.0 \%$, respectively), cycloartenol (24dehydrocycloartenol) (31.5\% and 8.9\%), $\beta$-amyrin (olean-12-enol) (28.5\% and $33.5 \%$ ) and 24-methylenecycloartanol (15.0\% and 9.6\%), among others. According to Cadena Iñiguez and Arévalo Galarza (2011) several cucurbitacins (tetracyclic triterpenoids) were identified in eight varieties of chayote,

including $\mathrm{Cu} \mathrm{B}, \mathrm{Cu} \mathrm{E}, \mathrm{Cu} \mathrm{P}$, and Cu Q1 glycosides, dihydrocucurbitacin-Q1, dihydroisocucurbitacin-I, glycocucurbitacin-I, dihydrocucurbitacin-D, isocucurbitacinD, dihydroisocucurbitacin-E, hydrocucurbitacin-E, isocucurbitacin-B, dihydroisocucurbitacin-B, cucurbitacin-L, cucurbitacin-E, and cucurbitacin-B. The green and wild varieties showed higher concentrations than the yellow varieties, suggesting that the higher cucurbitacins content may be related to the bitter flavour of chayote. 


\subsection{Amino acids and peptides}

A lectin from the exudate of chayote fruit, rich in glycine, leucine, asparagine/ aspartic acid, glutamine/ glutamic acid, and serine residues, was purified from chayote fruit

(Vozari-Hampe, Viegas, Saucedo, Rosseto, Manica \& Hampe, 1992). Also, twenty known Gibberellins' (Albone et al., 1984) and a new ribosome-inactivating protein (RIP), sechiumin, with antiproliferative inhibitory activities (Wu, Chow \& Lin, 1998) were purified from the seeds.

\subsection{Glucosidase inhibitors}

Glucosidases are a group of digestive enzymes that break down dietary carbohydrates into simple monosaccharides. Glucosidase inhibitors reduce the rate of carbohydrate digestion and delay the carbohydrate absorption from the digestive tract. Therefore, they have a potential to prevent the development of type 2 diabetes mellitus by lowering the glucose levels. Chayote presents inhibitory activity against carbohydrate-hydrolysing enzymes, namely $\alpha$-amylase, $\alpha$-glucosidase and $\beta$-Glucosidase enzymes (Sulaiman, Ooi, \& Supriatno, 2013; Mateos et al., 2015; Loizzo et al., 2016). Peel extract is the most active against $\alpha$-amylase with an $\mathrm{IC}_{50}$ value of $0.2 \mathrm{mg} / \mathrm{ml}$, and leaves and fresh pulp extracts show a more pronounced activity against $\alpha$-glucosidase. Both $\alpha$-amylase and aglucosidase inhibitory activities of chayote are positively correlated with the total phenolics and flavonoid contents (Loizzo et al., 2016).

\section{Impact of processing methods on nutritional and phytochemistry composition}

Cooking processes promote minor changes in the polysaccharide composition of chayote pulp, but strongly affect the phytochemical composition (Shiga et al., 2015; Castro-Alves \& do Nascimento, 2016). For instance, according to Loizzo et al. (2016), a 
significant loss of flavonoid content was observed with the following trend: fresh > steamed $\left(95^{\circ} \mathrm{C}\right.$ water under atmospheric pressure for $\left.30 \mathrm{~min}\right)>$ blanched $\left(100{ }^{\circ} \mathrm{C}, 30\right.$ $\min )>$ backed $\left(\right.$ dry heat at $190{ }^{\circ} \mathrm{C}$ for $\left.90 \mathrm{~min}\right)>\operatorname{microwaved}(10 \mathrm{~min}$ at $900 \mathrm{MHz})>$

roasted

$\left(180{ }^{\circ} \mathrm{C}\right.$ for $\left.10 \mathrm{~min}\right)$; also roasted and steamed processes reduced one-half of the concentration of total phenol content. The total carotenoid content was reduced with the following trend: fresh $>$ blanched $>$ microwaved $>$ roasted $>$ baked $>$ steamed; and the vitamin $\mathrm{C}$ content was reduced in the following order: fresh $>$ blanched $>$ backed $>$ microwaved $>$ roasted $>$ steamed. Also, within the cooking processes, protein and fibre contents of chayote fruit decreased to 0.62 and $2.80 \%$, respectively, as well as the contents of vitamins C, E and folic acid (Loizzo et al, 2016). Likewise, the canning process drastically reduced both total phenol and vitamin $\mathrm{C}$ content in the chayote (Ellong, Billard, Adenet, \& Rochefort, 2015).

\section{Pharmacological properties}

\subsection{General}

Clinical and epidemiological studies have established an inverse relation between the consumption of chayote and the prevalence of chronic diseases. This link depends on the bioactive compounds present in chayote composition. Chayote has been reported to present antibacterial (Ordoñez, Gomez, Cudmani, Vattuone, \& Isla, 2003; Ordonez, Ordonez, Zampini, \& Isla, 2009; Noumedem, Mihasan, Lacmata, Stefan, Kuiate \& Kuete, 2013); antioxidant (Ordoñez, Gomez, Vattuone, \& 1sla, 2006; Dire et al., 2007;

Ibarra-Alvarado et al., 2010; Yang, Chan, Lee, Chang, Wu, \& Wang, 2015); antihypertensive (Gordon, Guppy, \& Nelson, 2000; Ibarra-Alvarado et al., 2010) and antiepileptic (Firdous, Sravanthi, Debnath, \& Neeraja, 2012) activities. Table 3 gives a 
general overview of the biological activities of chayote, which have been pointed by in vitro and/ or in vivo pharmacological studies.

\subsection{Anti-cardiovascular properties}

Flavonoids present in chayote shoots were shown to $(a)$ decrease serum lipids and cholesterol content, preventing atherosclerosis and fatty liver ( $\mathrm{Wu}, \mathrm{Ou}$, Chang, Chang, Yang \& Wang, 2014), (b) reduce the oleic acid (OA)-induced hepatic lipid accumulation in HepG2 cells (Wu et al., 2014) and (c) modulate the hepatic lipid metabolism (Yang et al., 2015). Also, the hydroalcoholic roots extracts containing cinnamic acid methyl ester, coumaric acid and vitexin exhibited antihypertensive activity. When administered intravenously in anesthetized rats treated with angiotensin

II (AG II), these extracts and their fractions acted as a potent hypertension inducer (Lombardo-Earl et al., 2014). The aqueous extract of pulp and peel of chayote also exhibited hypotensive effect; although the mechanisms associated were not explained, results showed a fall in blood pressure with little change in electrocardiogram intervals (Gordon et al., 2000). The cardioprotective activity of the ethanolic extract of fruit was also determined in animal models. Results showed that Wistar rats treated with chayote fruit extract for 28 days significantly $(p<0.01)$ reduced the serum levels of several enzymes (SGOT, SGPT, ALP, LDH, CK), total cholesterol, triglycerides, LDLcholesterol, VLDL-cholesterol, and increased the levels of HDL-cholesterol (Neeraja, Debnath, \& Firdous, 2015). The angiotensin-converting enzyme (ACE) inhibitor nicotianamine was purified from chayote, however, its absorption and efficacy on reninangiotensin-aldosterone system was not highlighted (Hayashi, Nakayama, Aoyagi, $\&$

Kimoto, 2005). 


\subsection{Anti-diabetic properties}

The phenolic composition, especially the flavonoids and the polysaccharides fraction, have received major attention regarding their hypoglycaemic effects; these

phytochemicals may act through different mechanism of action, including (a) $\alpha$-amylase and $\alpha$-glucosidase inhibition, (b) prevention of $\beta$-cell apoptosis, $(c)$ promotion of $\beta$-cell proliferation and insulin secretion and activity (Loizzo et al., 2016). In an experimental study with diabetes induced Wistar rats, chayote peel extract induced protection of cells against cytotoxic- $\mathrm{SnCl}_{2}$ effects, probably due to the presence of antioxidant compounds, such as flavonoids and proteinases (Dire, Lima, Gomes, Faria, \& Bernardo-Filho, 2004). The same study further described that chayote extract was capable of reducing the plasma level of glucose and globulin (Dire et al., 2007). Also, the oral administration of chayote fruit juice was reported to accelerate the normalization of oral glucose tolerance ability and decrease the oxidative stress, platelet aggregation and the accumulation of Advanced Glycation End Products (AGEs) in sucrose induced impaired glucose tolerance and stressed rats (Tiwari, Anusha, Sumangali, Anand Kumar, Madhusudana \& Agawane, 2013). In addition, the oral administration of ethanolic extract of chayote fruit in diabetic rats $(100 \mathrm{mg} / \mathrm{kg}$ bw and $200 \mathrm{mg} / \mathrm{kg} \mathrm{bw}$ ) promoted the body weight loss, significantly ( $p$ $<0.01$ ) decreased the blood glucose level on $0,7,14$, and 21 day and improved the lipid profile (Maity, Firdous, \& Debnath, 2013). More recently, the oral administration of ethanolic extract of chayote fruits (100 and $200 \mathrm{mg} / \mathrm{kg} \mathrm{bw})$ to alloxan-induced diabetic rats promoted the body weight loss and significantly decreased the blood glucose levels (Loizzo et al., 2016). 


\subsection{Anti-obesity properties}

Chayote shoots can reduce the body weight, the adipose tissue, and regulate the hepatic lipid contents. The treatment of caffeic acid and hesperetin, the main phenolic compounds of chayote shoots, inhibited the oleic acid-induced lipid accumulation in HepG2 cells and the AMP-activating protein kinase (AMPK) phosphorylates, and

inactivated a number of metabolic enzymes involved in ATP consuming cellular events, including fatty acid and cholesterol synthesis (Wu et al., 2014). Recently, it was reported that chayote shoot extract enhanced the activation of AMPK and decreased numerous lipogenic-related enzymes, such as sterol regulator element-binding proteins and HMGCoA reductase proteins, which are critical regulators of hepatic lipid metabolism (Yang et al., 2015).

\subsection{Antioxidant properties}

Epidemiological studies indicate that a diet containing antioxidant compounds can protect the human body from free radicals and retard the progress of many chronic diseases (Ordoñez et al., 2006). Chayote leaves ethanolic extracts and seed aqueous extracts were reported to exhibit a strong inhibitory activity by $\beta$-carotene bleaching (antioxidant activity values of $90 \%$ ) and a strong reducing effect by a linoleate model (Ordoñez et al., 2006). This study suggested that flavonoids, namely flavonol, could be responsible for the antioxidant effects. Dire et al. (2007) showed that some components of chayote extracts present an oxidant power able to alter the biodistribution of sodium pertechnetate drug in induced diabetic rats. According to Sulaiman et al. (2013), gallic acid, caffeic acid and isoquercetin were identified as the most active antioxidant constituents in the ethyl acetate extract of dried chayote pulp. More recently, Chao et al. (2014) characterized the antioxidant profile of hydrolysates of green and yellow chayote leaves, founding 
significantly higher contents of myricetin (756.13 and $1010.54 \mu \mathrm{g} / 100 \mathrm{~g} \mathrm{dw}$, respectively); morin (194.99 and $404.38 \mu \mathrm{g} / 100 \mathrm{~g} \mathrm{dw}$ ) and anthocyanidins (1.42 and 1.12 $\mu \mathrm{g} / 100 \mathrm{~g} \mathrm{dw}$ ). According to Loizzo et al., (2016), the microwaved (10 min at $900 \mathrm{MHz}$ ) and blanched $\left(100{ }^{\circ} \mathrm{C}, 30 \mathrm{~min}\right)$ processes drastically reduced the radical scavenging activity of chayote peel and leaves.

\subsection{Anti-inflammatory properties}

The bioactive polysaccharides of chayote, mostly represented by arabinans and homogalacturonans, modulate macrophage functions. According to Castro-Alves and do Nascimento (2016), the biological effects observed, including the induced tumour necrosis factor alpha and nitric oxide secretion in macrophages, were not affected by the solubilization of chayote low molecular weight polysaccharides during the cooking process.

\subsection{Anti-ulcer properties}

The oral administration of ethanolic extract of chayote fruit $(500 \mathrm{mg} / \mathrm{kg} \mathrm{bw})$ showed a significant $(p<0.01)$ anti-ulcer activity in aspirin induced gastric ulceration in rats. This extract reduced total acidity, free acidity, gastric output and increases the $\mathrm{pH}$ of gastric secretion (Sateesh, Hussaini, Kumar, \& Rao, 2012).

\subsection{Anticancer properties}

The antioxidant potential of bioactive chayote compounds has been associated with the ability to inhibit some types of cancer. Six saponines showing antiproliferative activity (ED50: 10-74 $\mu \mathrm{g} / \mathrm{ml}$ ) against MK-1, HeLa and B16F10 tumour cells were isolated from the fruit and aerial parts of chayote (Castro et al., 1997). Also, a protein (27 kDa) isolated from seed aqueous extracts of chayote, called sechiumin, was claimed to possess 
ribosomal inactivation properties and potential chemotherapeutic activity (Wu et al., 1998; Yen, Chen, \& Peng, 2001). The alcoholic extract of chayote fruits presented antiproliferative and cytotoxic activity of dose-dependent type on L-929 and HeLa tumour cell lines; analysis by hydrogen nuclear magnetic resonance and gas

chromatography coupled to mass spectrometry revealed that saturated fatty acid ester was the principal component of the most active fraction (Monroy-Vázquez, SotoHernandez, Cadena-Iniguez, Santiago-Osorio, Ruiz-Posadas \& Rosas-Acevedo, 2009). More recently, chayote extract was shown to possess a positive effect on acute myeloid leukaemia treatment. Results showed that although the methanolic extract of chayote hybrid H-837-07-GISeM® fruit had no effect on the mononuclear cells of bone marrow (BM-MNCs), strongly inhibited the proliferation of the murine leukemic cell lines P388 (macrophagic), J774 (monocytic), and WEHI-3 (myelomonocytic) cell lines (with an $\mathrm{IC}_{50}$ below $1.3 \mu \mathrm{g} / \mathrm{ml}$ ). Likewise, the extract reduced cell viability and induced apoptotic body production, phosphatidylserine translocation and DNA fragmentation (AguiñigaSánchez et al., 2015).

\subsection{Anti-mutagenic properties}

Aqueous extracts of chayote present antimutagenic activity. Fractions with molecular weights above $30 \mathrm{kDa}$ showed the strongest antimutagenicity and peroxidase activities; the phenolic compounds presented in the extract were suggested as the heat-stable antimutagenic substances (Yen et al., 2001).

\subsection{Anti-microbial}

Chayote has been claimed to possess a wide variety of secondary metabolites, which presents different structures and actions comparable with conventionally used 
antimicrobials. Thus, the use of chayote and its derived products is a promising way to keep control of food borne pathogens (Sibi, Kaushik, Dhananjaya, Ravikumar, \& Mallesha, 2013). Aqueous and ethanolic extracts of leaf chayote exhibited antimicrobial activity against strains of multi-resistant staphylococci and enterococci; the highest

activity was obtained with the $80 \%$ aqueous extract (Ordoñez et al., 2003). Chayote extracts were similarly reported to show antimicrobial activity against Escherichia coli, Klebsiella pneumoniae, Proteus mirabilis, Enterobacter cloacae, Serratia marcescens,

Morganella morganii, Acinetobacter baumannii, Pseudomonas aeruginosa, Stenotrophomonas maltophilia, Candida spp. and Aspergillus spp. isolated from clinical samples from two hospitals of Tucuman in Argentina (Ordonez, Ordonez, Zampini, \& Isla, 2009). Another study reported that chayote fruits (pulp and seed) chloroform and methanolic extracts exhibited antibacterial activity against most of the Gram-negative bacteria tested (Escherichia coli ATCC 8739, Salmonella typhimurium ATCC 3224 and Shigella flexneri ATCC 12022) (Sibi et al., 2013).

\subsection{Anti-epileptic}

The effect of the ethanolic chayote fruit extract $(200 \mathrm{mg} / \mathrm{kg} \mathrm{bw})$ on antiepileptic and central nervous system depressant model was studied in animal models. Results showed a significant reduction of the duration of various phases of convulsions in both MESinduced seizures and in PTZ-induced convulsion, and a decrease of the locomotor activity in a dose dependent manner (Mumtaz, Ahmed, \& Dey, 2012a).

\subsection{Hepatoprotective properties}

The oral administration of chayote fruit ethanolic extracts (100 and $200 \mathrm{mg} / \mathrm{kg} \mathrm{bw}$ ) and its ethyl acetate and $n$-butanol fractions exhibited a significant hepatoprotective activity 
against tetrachloromethane induced hepatotoxicity in rats (Firdous et al., 2012). The effects observed included: (a) a reduction in the levels of aspartate aminotransferase (AST), alanine aminotransferase (ALT), alkaline phosphatase (ALP), total bilirubin, and hepatic lipid peroxidation and $(b)$ a hike in the levels of antioxidant markers, such as

hepatic

glutathione (GSH), catalase (CAT), superoxide dismutase (SOD), and total protein in a dose-dependent manner. Also, the aqueous extract of chayote leaves possessed a protective effect against gentamicin- and potassium dichromate-induced nephrotoxicity and streptozotocin-induced diabetic nephropathy (Mumtaz, Paul, \& Bag, 2012b). According to Wu et al. (2014) and Yang et al. (2015), the polyphenol components of chayote shoots attenuated hepatic lipid accumulation that results in a fatty liver. In animal models, these authors observed that the chayote shoots extracts reduced the adipose tissue fat and regulate hepatic lipid contents (e.g. triglycerides and cholesterol).

\section{Uses and potential applications}

\subsection{General}

The short shelf life of chayote has led to research efforts to make processed products. Other potential applications of the different parts of chayote plant are the cosmetic, pharmaceutical and nanomaterials industries, as well as its use in biotechnological processes. Chayote fields are routinely cleared for replanting, this practice produces large amounts of root which are destroyed despite its potentially high commercial value. Also, fruits that are not in accordance with market classification standard are wasted (Shiga et al., 2015). However, while these by-products create greater mass and contain active compounds, their recovery can be used for development of new products with added-commercial value in food, cosmetic and pharmaceutical industries. Fig. 2 presents the main application fields of chayote plant. 


\subsection{Food products}

Chayote tuber is a valuable source of starch, which presents morphological,

physicochemical and molecular characteristics that are comparable to the traditional potato starch (Hernandez Uribe, Agama Acevedo, Gonzalez Soto, Bello Pérez, \& Vargas Torres, 2011). Additionally, chayote starch is a good substitute for wheat flours in diverse products, which can be used by people with special nutritional requirements, such as those with celiac disease (Hernandez-Uribe et al., 2014). The softness of the fruit makes it particularly appropriate for hospital diets and for giving consistency to baby foods, juices, sauces and pasta dishes (Siciliano et al., 2004; Loizzo et al., 2016). However, it has a delicate flesh and high moisture content, making it highly perishable. Thus, there is a growing interest to make processed products from chayote; food and beverage markets are promising fields. A feasible way to extend the shelf life of chayote is by reducing their moisture content (Shiga et al., 2015). Oliveira, Srur and Vacari (2003) produced a final product of crystalized chayote with moisture content of $12.5 \%$, yield of $82 \%$ and good consumer's acceptance. Convective drying is the most widely used technique for production of dehydrated chayote (Ruiz-López, Huerta-Mora, Vivar-Vera, MartinezSanchez, \& Herman-Lara, 2010). Moreover, chayote has been processed into jams (Shiga et al., 2015), sweet and pickles ( $\mathrm{Li}, 2011)$ and sauce, to be used as a substitute for apple in pies and tarts (Huang et al., 2011).

\subsection{Folk medicine}

Chayote is widely recognized and used in different parts of the world for the treatment of several diseases, including diabetes, constipation, leprosy, asthma, bronchitis, jaundice, joint pain, cancer and mastitis (Aung et al., 1990). For instance, the fruit is used as a 
laxative and as a therapeutic agent against renal diseases to dissolve kidney stones (Bermejo \& León, 1994; Gordon et al., 2000; Kamble, Dumbre \& Rangari, 2008), as well as in the treatment of arteriosclerosis, hypertension (Lombardo-Earl et

al.,

2014), severe hypokalemia in pregnancy (Jensen \& Lai, 1986), ulcer healing and intestinal, and cutaneous inflammation (Siciliano et al., 2004; Aguiñiga-Sánchez et al., 2015). In Mexico, its use is also reported for treating symptoms of severe headaches, nervousness and anxiety (Lombardo-Earl et al., 2014). Due its low content in calories and fibrous, chayote fruit also supports weight loss efforts. Infusions of the leaves are used to dissolve kidney stones and to assist in the treatment of arteriosclerosis and hypertension (Bermejo \& León, 1994), as well as in suppuration of boils as they exhibit antiulcer, laxative, anti-inflammatory and diuretic properties (Gordon et al., 2000; Lombardo-Earl et al., 2014).

\subsection{Cosmetic products}

Chayote has found an extensive application in the cosmetic and toiletry industries, such as moisturizers, cleansers, sun lotions, toothpastes, mouthwashes, shaving creams, deodorants and shampoos. Wang, Shih and Chang (2017) claimed an invention that provides an extraction method of a chayote fruit to be applied in skincare products (chayote fruit mask), cosmetics, and pharmaceutical products. After the application of this chayote fruit mask to female volunteers`skin, it was observed a notable wrinklesmoothing effect. More recently, Metral et al. (2018) observed that a chayote fruit extract protected keratinocytes against UVA-induced cytotoxicity and decreased the intracellular amounts of reactive oxygen species, suggesting a potential cytoprotective and genopreventive effects. 


\subsection{Pharmacological formulations}

The Bio-catalyzer $\alpha \cdot \varrho$ No. 11 (Bio-normalyzer) is a health product produced by glucose fermentation of Carica papaya Linn, Penisetum pupureum and Sechium edule. This

product

is claimed to exert activity against neural lipid peroxidation, traumatic epilepsy and aging (Santiago, Osato, Hiramatsu, Edamatsu, \& Mori, 1991). Marotta et al. (2001) found that oral administration of Bio-normalyzer (18 g/day for 2 weeks) by alcoholic patients with haemorheological abnormalities resulted in a significant restoration to control values of blood viscosity and an improvement of red blood cell membrane fluidity, red blood cell malonyldialdehyde and plasma glutathione. More recently, Ordonez et al. (2009) produced a hydrogel with carbopol acrylic acid polymer containing chayote fluid extract, which activity is comparable with commercial pharmaceutical formulations. This topical formulation can be used as antibacterial, antimycotic and antioxidant agent in cutaneous infections.

\subsection{Nano-materials}

Nano-materials have been recognized to be effective in many applications, as biomedical, drug-delivery, photochemical, beauty-care, nano-pigments, and sensor development (Chelli, Bag, \& Golder, 2016; Koduru et al., 2018). Elavarasan, Kokila, Inbasekar \& Sujatha (2016) reported the synthesis of zinc oxide nanoparticles (ZnONPs) using chayote leaf extract, showing significant cytotoxicity to MCF-7 breast cancer cells ( IC $_{50}$ of 3.5 $\mu \mathrm{g} / \mathrm{ml})$ and antibacterial activity against Bacillus subtilis and

Klebsiella pneumonia. Also, Chelli et al. (2016) developed a simple and eco-friendly method for the synthesis of spherical silver nanoparticles (AgNPs) using the aqueous extract of chayote fruit. AgNPs were found to serve as both reducing and capping agents, being highly effective against pathogenic fungi Aspergillus thermomutans. More recently, 
starch extracted from chayote tubers was modified with the aim to increase its resistant starch content for further investigation as a promising wall material for microcapsules containing ascorbic acid. This technique was shown to improve the

stability of ascorbic acid during storage and ensure its controlled release, increasing its efficiency and bioavailability (Martínez-Ortiz et al., 2017).

\subsection{Biotechnology}

Chayote is a source of several enzymes, such as polyphenoloxidase, alcohol dehydrogenase, catalase, phosphatase, lipoxygenase and peroxidase, which can be used in biotechnological processes (Flick, Jr., Burnette, Aung, Ory, \& Saint Angelo, 1978). Alonso, Chávez, Polo, Ayala, Vidal \& Salazar (2016) showed that peroxidases extracted from chayote were efficient in the removal of pentachlorophenol, a mutagenic and persistent halogenated hydrocarbon pesticide used for preserving wood against fungi, bacteria and insects. From action of these oxidoreductases, free radicals are generated which are polymerized to low toxicity products. Furthermore, chayote seeds possess low molecular weight trypsin inhibitors, which can be used in a synthesis program for the development of new protease inhibitors of biological interest by modifying their amino acid sequences (Laure, Faca, Izumi, Padovan, \& Greene, 2006).

\subsection{Animal nutrition}

Trials have been conducted to use fruits, shoots and tubers as fodder, in erosion control (Shiga et al., 2015). Chayote seems to play an important role in promoting growth in pigs, poultry and cattle or in their health management. Lalthansanga and Samanta (2015) studied the growth and nutrient utilization of Zovawk pigs fed on different levels of chayote meal (fruits and leaves) in the diet. After a 90-day feeding trial, it was found that 
chayote meal could safely replace the standard grower ration up to $40 \%$ in the diet of pigs without causing any adverse effects on growth and nutrient utilization.

\subsection{Other applications}

Chayote flowers are reported to be good nectar sources for beers (Bermejo \& León, 1994; Lim, 2012), and due to its flexibility and strength, chayote stem fibres have been used in the paper industry and craft manufacture of baskets, hats and shade fish ponds.

\section{Conclusions and future perspectives}

It is well documented that the edible parts of chayote contain high levels of various healthenhancing substances with potential applications in food, cosmetic and pharmaceutical industries. However, limited attention has been given to underutilized or neglected crops, chayote by-products are an excellent source of bioactive compounds and its use could become an important aspect in waste management from both economic and environmental standpoints. Therefore, the recovery and utilization of valuable compounds from chayote (and its by-products) is an important challenge for scientists towards the promotion of large-scale use. In this sense, eco-friendly recovery techniques should be implemented. Scientific investigation to identify the physiologically active substances from chayote should continue. Using appropriate technology, inexpensive active compounds can be obtained, and thus, it is important to comprehensively study the bioavailability of those bioactive compounds in the organism. Equally important is the extension of research on the medicinal potential of chayote, through in vitro, in vivo experiments and clinical trials, as well as the evaluation of the sensorial and nutritional aspects and safety of the new products containing chayote extracts. With the investigative growth, new businesses opportunities to valorise chayote can be created 
and marketing studies should be conducted to realize its potential value.

\section{Acknowledgments}

This work was supported by European Union (FEDER funds through COMPETE) and

National Funds (Fundação para a Ciência e a Tecnologia) through the project UID/QUI/50006/2013.

\section{Author Contributions}

Elsa F. Vieira wrote the manuscript; Olívia Pinho, Isabel IMPLVO Ferreira reviewed the paper and Cristina Delerue-Matos supervised and reviewed the paper.

\section{Conflicts of Interest}

The authors declare no conflict of interest.

\section{References}

Aguiñiga-Sánchez, I., Soto-Hernández, M., Cadena-Iñiguez, J., Ruíz-Posadas, L. d. M., Cadena-Zamudio, J. D., González-Ugarte, A. K., Benny Weiss Steider, B. W. \& Santiago-Osorio E. (2015). Fruit extract from a Sechium edule hybrid induce apoptosis in leukaemic cell lines but not in normal cells. Nutrition and cancer,

67, 250-257. 
Akihisa, T., Ghosh, P., Thakur, S., Rosenstein, F.U., \& Matsumoto, T. (1986). Sterols compositions of seeds and mature plants of family Cucurbitaceae. Journal of the American Oil Chemists' Society, 63, 653-658.

Albone, K. S., Gaskin, P., MacMillan, J., \& Sponsel, V. M. (1984). Identification and localization of gibberellins in maturing seeds of the cucurbit Sechium edule, and a comparison between this cucurbit and the legume Phaseolus coccineus. Planta, 162, 560-565.

Alonso, A. I. A., Chávez, E., Polo, D., Ayala, E., Vidal, E., \& Salazar, G. (2016). Removal of pentachlorophenol using chayote (Sechium edule Sw) peroxidase. Toxicology Letters, 259, Supplement, S225.

Aung, L. H., Ball, A., \& Kushad, M. (1990). Developmental and nutritional aspects of chayote (Sechium edule, Cucurbitaceae). Economic botany, 44, 157-164.

Bellur Nagarajaiah, S., \& Prakash, J. (2015). Chemical composition and bioactive potential of dehydrated peels of Benincasa hispida, Luffa acutangula, and Sechium edule. Journal of Herbs, Spices \& Medicinal Plants, 21, 193-202.

Bermejo, J. E. H., \& León, J. (1994). Neglected crops: 1492 from a different perspective. Plant Production and Protection Series No. 26, Food and Agriculture Organization of the United States, Rome, (pp. 63-77).

Booth, S., Bressani, R., \& Johns, T. (1992). Nutrient content of selected indigenous leafy vegetables consumed by the Kekchi people of Alta Verapaz, Guatemala. Journal of Food Composition and Analysis, 5, 25-34.

Cadena Iñiguez, J., \& Arévalo Galarza, M.L. (2011). Las variedades del chayote mexicano, recurso ancestral com potencial de comercialización. Grupo Interdisciplinario de Investigación en Sechium edule en México, A.C. Colegio de Postgraduados, Mexico.

Cadena-Iñiguez, J., Arévalo-Galarza, L., Avendaño-Arrazate, C. H., Soto-Hernández, 
M., Ruiz-Posadas, L. d. M., Santiago-Osorio, E., Acosta-Ramos, M., CisnerosSolano, V. M., Aguirre-Medina, J. F., \& Ochoa-Martínez, D. (2007). Production, genetics, postharvest management and pharmacological characteristics of Sechium edule (Jacq.) Sw. Fresh produce, 1, 41-53.

Castro, V. H., Eamirez, E., Iwase, Y., Nagao, T., Okabe, H., Matsunaga, H., \& Katano, M. (1997). Structures and antiproliferative activity of saponins from Sechium pittieri and S. talamancense. Chemical and pharmaceutical bulletin, 45, 349358.

Castro-Alves, V. C., \& do Nascimento, J. R. O. (2016). Polysaccharides from raw and cooked chayote modulate macrophage function. Food Research International, 81, 171-179.

Chao, P.-Y., Lin, S.-Y., Lin, K.-H., Liu, Y.-F., Hsu, J.-I., Yang, C.-M., \& Lai, J.-Y. (2014). Antioxidant activity in extracts of 27 indigenous Taiwanese vegetables. Nutrients, 6, 2115-2130.

Chelli, V. R., Bag, S. S., \& Golder, A. K. (2017). A biosynthesis route to nearly spherical AgNPs using chayote fruit extract. Environmental Progress \& Sustainable Energy, 36, 192-199.

Del Ángel Coronel, O.A. 2015. Determinación de la actividad de lipoxigenasa y evaluación de eficiencias de transformación mediada por Rhizobium spp. Y biobalística en chayote (Sechium edule Jacq. Sw. var. virens levis). Tesis de Doctorado, Unidad de Investigación y Desarrollo en Alimentos del Instituto Tecnológico de Veracruz, Veracruz, México. Dire, G. F., Almeida, M. C., Coura, M. F., Vasconcelos, S. D., Siqueira, P. R., Duarte,

R. M., Rodrigues, J. S., Oliveira, J. C. S., Fernandes, M. L., \& Bernardo-Filho, M. (2007). Effects of a chayote (Sechium edule) extract (macerated) on the 
biochemistry of blood of Wistar rats and on the action against the stannous chloride effect. Pakistan Journal of Biological Sciences, 10, 823-827.

Dire, G., Lima, E., Gomes, M., Faria, M. C., \& Bernardo-Filho, M. (2004). Study of the effects of a chayotte (Sechium edule) extracts on the plamid pUC 9.1 DNA. Food and Chemical toxicology, 2, 195-199.

Elavarasan, N., Kokila, K., Inbasekar, G., \& Sujatha, V. (2016). Evaluation of photocatalytic activity, antibacterial and cytotoxic effects of green synthesized $\mathrm{ZnO}$ nanoparticles by Sechium edule leaf extract. Research on Chemical Intermediates, 43, 3361-3376.

Ellong, E. N., Billard, C., Adenet, S., \& Rochefort, K. (2015). Polyphenols, carotenoids, vitamin c content in tropical fruits and vegetables and impact of processing methods. Food and Nutrition Sciences, 6, 299-313.

Fidrianny, I., \& Darmawati, A. (2014). Antioxidant capacities from different polarities extracts of Cucurbitaceae leaves using FRAP, DPPH assays and correlation with phenolic, flavonoid, carotenoid content. International Journal of Pharmacy and Pharmaceutical Sciences, 6, 58-62.

Fidrianny, I., Darmawati, A \& Hartati, R. (2015). Antioxidant capacities, phenolic, flavonoid and carotenoid content of various polarities extracts from three organs of Sechium edule (Jacq.) Swartz. Journal of Chemical and Pharmaceutical Research, 7, 914-920.

Fidrianny, I., Kevin, \& Hartati, R. (2016). Evaluation of antioxidant activities of fruit extracts of chayote (Sechium edule [Jacq.] Swartz) grown in different sites in java-Indonesia. Asian Journal of Pharmaceutical and Clinical Research, 9, 270-275.

Firdous, S., Sravanthi, K., Debnath, R., \& Neeraja, K. (2012). Protective effect of ethanolic extract and its ethylacetate and n-butanol fractions of Sechium edule 
fruits against carbon tetrachloride induced hepatic injury in rats. International Journal of Pharmacy and Pharmaceutical Sciences, 4, 354-359.

Flick, G. J., Aung, L. H., Ory, R. L., \& Angelo, A. J. (1977). Nutrient Composition and selected enzyme activities in Sechium edule, SW, the mirliton. Journal of Food Science, $42,11-13$.

Flick, G. J., Jr., Burnette, F. S., Aung, L. H., Ory, R. L., \& Saint Angelo, A. J. (1978). Chemical composition and biochemical properties of mirlitons (Sechium edule) and purple, green, and white eggplants (Solanum melongena). Journal of Agricultural and Food Chemistry, 26, 1000-1005.

Gordon, E. A., Guppy, L. J., \& Nelson, M. (2000). The antihypertensive effects of the Jamaican Cho-Cho (Sechium edule). West Indian Medical Journal, 49, 27-31.

Hayashi, A., Nakayama, T., Aoyagi, Y., \& Kimoto, K. (2005). Purification of nicotianamine from hayatouri (Sechium edule) and estimation of quantitative determination method. Journal of the Japanese Society for Food Science and Technology.

Hernandez. Uribe, J. P., Agama_ Acevedo, E., Gonzalez_ Soto, R. A., Bello_ Pérez, L. A., \& Vargas_ Torres, A. (2011). Isolation and characterization of Mexican chayote tuber (Sechium edule Sw.) starch. Starch, 63, 32-41.

Hernandez-Uribe, J. P., García-Suárez, F. J., Gutiérrez-Meraz, F., Rodriguez-Ambriz, S. L., \& Bello-Perez, L. A. (2014). By-products derived of the starch isolation from tubers: Physicochemical and functional properties. Journal of Food,

Agriculture and Environment, 12, 43-46.

Huang, L., Yang, J., Lin, D.-q., Liu, H.-w., Yuan, L.-p., Li, D.-m., Xu-guang, L. (2011). Study on the processing technology of sauced chayote. China Condiment, 7 , 19. 
Ibarra-Alvarado, C., Rojas, A., Mendoza, S., Bah, M., Gutiérrez, D., HernándezSandoval, L., Martínez, M. (2010). Vasoactive and antioxidant activities of plants used in Mexican traditional medicine for the treatment of cardiovascular diseases. Pharmaceutical biology, 48, 732-739.

Jensen, L. P., \& Lai, A. R. (1986). Chayote (Sechium edule) causing hypokalemia in pregnancy. American journal of obstetrics and gynecology, 155, 1048-1049.

Jiménez-Hernández, J., Salazar-Montoya, J. A., \& Ramos-Ramírez, E. G. (2007). Physical, chemical and microscopic characterization of a new starch from chayote (Sechium edule) tuber and its comparison with potato and maize starches. Carbohydrate Polymers, 68, 679-686.

Kamble, M., Dumbre, R., \& Rangari, V. (2008). Hepatoprotective activity studies of herbal formulations. International Journal of Green Pharmacy, 2, 147-151.

Kim, M.-J., Hyun, J. M., Kim, S. S., Seong, K. C., Lim, C. K., \& Kang, J.-S. (2016). In vitro screening of subtropical plants cultivated in Jeju Island for cosmetic ingredients. Oriental Journal of Chemistry, 32, 807-815.

Koduru, J. R., Kailasa, S. K., Bhamore, J. R., Kim, K.-H., Dutta, T., \& Vellingiri, K. (2018). Phytochemical-assisted synthetic approaches for silver nanoparticles antimicrobial applications: A review. Advances in Colloid and Interface Science, $256,326-339$.

Koehnlein, E. A., Koehnlein, É. M., Corrêa, R. C. G., Nishida, V. S., Correa, V. G., Bracht, A., \& Peralta, R. M. (2016). Analysis of a whole diet in terms of phenolic content and antioxidant capacity: effects of a simulated gastrointestinal digestion. International journal of food sciences and nutrition, 67, 614-623. 
Lalthansanga, J., \& Samanta, A. K. (2015). Effect of feeding chayote (Sechium edule) meal on growth performance and nutrient utilization in indigenous pig (Zovawk) of Mizoram. Veterinary World, 8, 918-923.

Laure, H. J., Faca, V. M., Izumi, C., Padovan, J. C., \& Greene, L. J. (2006). Low molecular weight squash trypsin inhibitors from Sechium edule seeds. Phytochemistry, 67, 362-370.

Li, H. (2011). Processing technology of acid and sweet chayote. Food Research and Development, 4, 27.

Lim, T. (2012). Sechium edule. In Edible Medicinal and Non-Medicinal Plants (pp. 384-391). Springer, Dordrecht.

Loizzo, M. R., Bonesi, M., Menichini, F., Tenuta, M. C., Leporini, M., \& Tundis, R. (2016). Antioxidant and carbohydrate-hydrolysing enzymes potential of Sechium edule (Jacq.) Swartz (Cucurbitaceae) peel, leaves and pulp fresh and processed. Plant Foods for Human Nutrition, 71, 381-387.

Lombardo-Earl, G., Roman-Ramos, R., Zamilpa, A., Herrera-Ruiz, M., Rosas-Salgado, G., Tortoriello, J., \& Jiménez-Ferrer, E. (2014). Extracts and fractions from edible roots of Sechium edule (Jacq.) Sw. with antihypertensive activity.

Evidence-Based Complementary and Alternative Medicine, 2014, 1-9.

Machida-Hirano, R., Cortés-Cruz, M., González, B. A. A., Íñiguez, J. C., Shirata, K., \& Watanabe, K. N. (2015). Isolation and characterization of novel microsatellite markers in chayote [Sechium edule (Jacq.) Sw.]. American Journal of Plant Sciences, 6, 2033-2041.

Maity, S., Firdous, S., \& Debnath, R. (2013). Evaluation of antidiabetic activity of ethanolic extract of Sechium edule fruits in alloxan-induced diabetic rats. World Journal of Pharmacy and Pharmaceutical Sciences, 2, 3612-3621. 
Marotta, F., Safran, P., Tajiri, H., Princess, G., Anzulovic, H., Ideo, G. M., Rouge, A., Seal, M. G. \& 1deo, G. (2001). Improvement of hemorheological abnormalities in alcoholics by an oral antioxidant. Hepatogastroenterology, 48, 511-517.

Martínez-Ortiz, M. A., Vargas-Torres, A., Román-Gutiérrez, A. D., ChavarríaHernández, N., Zamudio-Flores, P. B., Meza-Nieto, M., Palma-Rodríguez, H. M. (2017). Partial characterization of chayotextle starch-based films added with ascorbic acid encapsulated in resistant starch. International Journal of Biological Macromolecules, 98, 341-347.

Mateos, S. E., Cervantes, C. A., Zenteno, E., Slomianny, M. C., Alpuche, J., HernandezCruz, P., Martínez-Cruz, R., Canseco, M. S. P., Pérez-Campos, E., Rubio, M. S., Mayoral, L. P.-C., \& Martínez-Cruz, M. (2015). Purification and partial characterization of beta-glucosidase in chayote (Sechium edule). Molecules, 20, $19372-19392$.

Melo, E. d. A., Lima, V., Maciel, M., Caetano, A. d. S., \& Leal, F. (2006). Polyphenol, ascorbic acid and total carotenoid contents in common fruits and vegetables. Brazilian Journal of Food Technology, 9, 89-94.

Metral, E., Rachidi, W., Damour, O., Demarne, F., \& Bechetoille, N. (2018). Long _term genoprotection effect of Sechium edule fruit extract against UVA irradiation in keratinocytes. Photochemistry and photobiology, 94, 343-350.

Mishra, L. K., \& Das, P. (2015). Nutritional evaluation of squash (Sechium Edule) germplasms collected from Garo Hills of Meghalaya-North East India. International Journal of Agriculture, Environment and Biotechnology, 8, 971.

Modgil, M., Modgil, R., \& Kumar, R. (2004). Carbohydrate and mineral content of chayote (Sechium edule) and bottle gourd (Lagenaria siceraria). Journal of Human Ecology, 15, 157-159. 
Monroy-Vázquez, M. E., Soto-Hernandez, M., Cadena-Iniguez, J., Santiago-Osorio, E., Ruiz-Posadas, L. d. M., \& Rosas-Acevedo, H. (2009). Bio-guided study of an alcoholic extract of Sechium edule (Jacq.) Swartz fruits. Agrociencia, 43, 777790.

Mumtaz, S. M. F., Ahmed, S., \& Dey, S. (2012a). Antiepileptic and central nervous system depressant activity of Sechium edule fruit extract. Bangladesh Journal of Pharmacology, 7, 199-202.

Mumtaz, S. M. F., Paul, S., \& Bag, A. K. (2012b). Effect of Sechium edule on chemical induced kidney damage in experimental animals. Bangladesh Journal of Pharmacology, 8, 28-35.

Neeraja, K., Debnath, R., \& Firdous, S. (2015). Cardioprotective activity of fruits of Sechium edule. Bangladesh Journal of Pharmacology, 10, 125-130.

Noumedem, J. A., Mihasan, M., Lacmata, S. T., Stefan, M., Kuiate, J. R., \& Kuete, V. (2013). Antibacterial activities of the methanol extracts of ten Cameroonian vegetables against Gram-negative multidrug-resistant bacteria. $\quad$ BMC complementary and alternative medicine, 13, 1-9

Oliveira, L., Srur, A. U. O. S., \& Vacari, F. (2003). Aproveitamento do chuchu (Sechium edule, Swartz) pelo processo de saturação com açúcar: uma alternativa alimentar. Revista Universidade Rural, 22, 09-14.

Ordoñez, A. A. L., Gomez, J. D., Cudmani, N. M., Vattuone, M. A., \& Isla, M. I. (2003). Antimicrobial activity of nine extracts of Sechium edule (Jacq.) Swartz. Microbial Ecology in Health and Disease, 15, 33-39.

Ordoñez, A. A. L., Gomez, J. D., Vattuone, M. A., \& 1sla, M. I. (2006). Antioxidant activities of Sechium edule (Jacq.) Swartz extracts. Food Chemistry, 97, 452458. 
Ordonez, A. A., Ordonez, R. M., Zampini, I. C., \& Isla, M. I. (2009). Design and quality control of a pharmaceutical formulation containing natural products with antibacterial, antifungal and antioxidant properties. International Journal of Pharmaceutics, 378, 51-58.

Ragasa, C. Y., Biona, K., \& Shen, C.-C. (2014). Chemical constituents of Sechium edule (Jacq.) Swartz. Der Pharma Chemica, 6, 251-255.

Rao, K.S., Dominic, R., Singh, K., Kaluwin, C., Rivett, D.E., \& Jones, G.P. (1990). Lipid, fatty acid, amino acid, and mineral compositions of five edible plant leaves. Journal of Agricultural and Food Chemistry, 38, 2137-2139.

Rietjens, I. M., Boersma, M. G., de Haan, L., Spenkelink, B., Awad, H. M., Cnubben, N. H., Jelmer J. van Zanden, Hester van der Woude, Gerrit M.Alink, \& Koeman, J. H. (2002). The pro-oxidant chemistry of the natural antioxidants vitamin C, vitamin E, carotenoids and flavonoids. Environmental toxicology and pharmacology, 11, 321-333.

Ruiz-López, I. I., Huerta-Mora, I. R., Vivar-Vera, M. A., Martinez-Sanchez, C. E., \& Herman-Lara, E. (2010). Effect of osmotic dehydration on air-drying characteristics of chayote. Drying Technology, 28, 1201-1212.

Saade, R. L. (1996). Chayote. Sechium edule (Jacq.) Sw. In: J. Heller, J. Engels, \& K. Hammer (Eds), Promoting the conservation and use of underutilized and neglected crops. International Plant Genetic Resources Institute. Rome, Italy.

Santiago, L. A., Osato, J. A., Hiramatsu, M., Edamatsu, R., \& Mori, A. (1991). Free radical scavenging action of bio-catalyzer $\alpha \cdot \varrho$ No. 11 (bio-normalyzer) and its by-product. Free Radical Biology and Medicine, 11, 379-383.

Sateesh, G., Hussaini, S. F., Kumar, G. S., \& Rao, B. S. S. (2012). Anti-ulcer activity of Sechium edule ethanolic fruit extract. The Pharma Innovation, 1, 77-81. 
Shiga, T. M., Peroni-Okita, F. H. G., Carpita, N. C., Lajolo, F. M., \& Cordenunsi, B. R. (2015). Polysaccharide composition of raw and cooked chayote (Sechium edule Sw.) fruits and tuberous roots. Carbohydrate Polymers, 130, 155-165.

Sibi, G., Kaushik, K., Dhananjaya, K., Ravikumar, K., \& Mallesha, H. (2013). Antibacterial activity of Sechium edule (Jacq.) Swartz against Gram negative food borne bacteria. Advances in Applied Science Research, 4, 259-261.

Siciliano, T., De Tommasi, N., Morelli, I., \& Braca, A. (2004). Study of flavonoids of Sechium edule (Jacq) Swartz (Cucurbitaceae) different edible organs by liquid chromatography photodiode array mass spectrometry. Journal of Agricultural and Food Chemistry, 52, 6510-6515.

Sriwichai, W., Berger, J., Picq, C., \& Avallone, S. (2016). Determining factors of lipophilic micronutrient bioaccessibility in several leafy vegetables. Journal of Agricultural and Food Chemistry, 64, 1695-1701.

Sulaiman, S. F., Ooi, K. L., \& Supriatno. (2013). Antioxidant and $\alpha$-glucosidase inhibitory activities of cucurbit fruit vegetables and identification of active and major constituents from phenolic-rich extracts of Lagenaria siceraria and Sechium edule. Journal of Agricultural and Food Chemistry, 61, 10080-10090.

Tiwari, A., Anusha, I., Sumangali, M., Anand Kumar, D., Madhusudana, K., \& Agawane, S. (2013). Preventive and therapeutic efficacies of Benincasa hispida and Sechium edule fruit's juice on sweet-beverages induced impaired glucose tolerance and oxidative stress. Pharmacologia, 4, 197-207.

USDA, United States Department of Agriculture Research Service (2016). https://ndb.nal.usda.gov/ndb/.

Vozari-Hampe, M. M., Viegas, C., Saucedo, C., Rosseto, S., Manica, G. G., \& Hampe, 
O. G. (1992). A lectin from Sechium edule fruit exudate. Phytochemistry, 31, 1477-1480.

Wang, H. K., Shih, Y. J., \& Chang, C. H. (2017). Chayote fruit cell fluid, preparation method thereof, skincare and wrinkle-smoothing composition including the same, and method of preparing wrinkle-smoothing composition. In: Google Patents.

Wu, C.-H., Ou, T.-T., Chang, C.-H., Chang, X.-Z., Yang, M.-Y., \& Wang, C.-J. (2014). The polyphenol extract from Sechium edule shoots inhibits lipogenesis and stimulates lipolysis via activation of AMPK signals in HepG2 cells. Journal of Agricultural and Food Chemistry, 62, 750-759.

Wu, T. H., Chow, L. P., \& Lin, J. Y. (1998). Sechiumin, a ribosome_ inactivating protein from the edible gourd, Sechium edule Swartz. European Journal of Biochemistry, 255, 400-408.

Yang, M.-Y., Chan, K.-C., Lee, Y.-J., Chang, X.-Z., Wu, C.-H., \& Wang, C.-J. (2015). Sechium edule shoot extracts and active components improve obesity and a fatty liver that involved reducing hepatic lipogenesis and adipogenesis in high- 
fat-diet-fed rats. Journal of Agricultural and Food Chemistry, 63, 4587-4596.

Yen, G., Chen, H., \& Peng, H. (2001). Evaluation of the cytotoxicity, mutagenicity and antimutagenicity of emerging edible plants. Food and Chemical toxicology, 39, 1045-1053.

\section{Tables and Figures caption}

Table 1. Nutritional composition of different edible parts of chayote plant 
Table 2. General content of the main bioactive compounds in different parts of chayote plant

Table 3. Pharmacological effects of different parts of chayote plant

Fig. 1 Left illustration shows the chayote plant with (a) staminate flowers, $(b)$ leaves, (c) roots and (d) fruit [adapted from (Saade, 1996)]. Right ill ustration represents a sample of the diversity of cultivated chayote found in the global market.

Fig. 2 Schematic representation of chayote valorisation. 
